\title{
15. The Materiality of Missionisation in Collingwood Bay, Papua New Guinea
}

\author{
Anna-Karina Hermkens \\ The Australian National University
}

\section{Introduction}

Or Manua, perhaps the greatest transformation of all was Manua. She came to us because Samuel Siru, one of the South Sea Island teachers in Collingwood Bay, wished to marry her. Samuel was stationed at Sinapa, a place where we had made very little impression, but Samuel had won the affection of Manua, and he knew and she knew that he ought not to marry a raw heathen; so when he made arrangements with her people about the marriage he said he wanted the young lady to go to Dogura to be trained and taught, so that she could be baptized before they were married. ${ }^{1}$

The physical and mental transformation Henri Newton refers to was inscribed in Manua's body during her two years stay in Dogura. ${ }^{2}$ At the centre of the expanding Anglican Mission, she would learn all the female duties involved in missionary housekeeping. When brought back to Sinapa village by Samuel, she was no longer the young Manua who had just been initiated into womanhood, which was designated by her fresh facial tattoo, her fully decorated body rubbed with coconut and her new tapa skirt (see Figure 33). ${ }^{3}$ Decorations, oil and tapa cloth are an essential part of Maisin bodily strength and well-being but these attributes of Maisin health and beauty were stripped from Manua's body. In Dogura, as Newton so vividly describes, ${ }^{4}$ Manua was transformed from

\footnotetext{
1 Henri Newton, In Far New Guinea, London: Seeley Service, 1914, p. 266. Newton was head of Dogura Mission Station until he became Bishop of the Anglican Church.

2 The archival research on which this paper is based was carried out in the Michael Somare Library of the University of Papua New Guinea and at The Australian National University in 2004. I thank the Anglican Church for granting me permission to access and study their rich archives and the staff of the Michael Somare Library for their friendly assistance. In addition, I consulted the National Museum and Art Gallery of Papua New Guinea, the Museum der Kulturen (Basel), the National Museum of Ethnology (Leiden), the Australian Museum (Sydney), the Queensland Museum (Brisbane), the British Museum (London), the National Museum of Scotland, the Marischal Museum of the University of Aberdeen, and the Museum für Volkerkunde (Vienna). 3 Newton, In Far New Guinea, p. 266.

4 Ibid., pp. 266-69.
} 
a frightened, dirty and smelly heathen girl into Sara-a nice-looking, clean, young Christian woman dressed in Western clothes. She would be the second Maisin to receive baptism. ${ }^{5}$ In 1909, Sara married Samuel Siru, who had come from Guadalcanal (Solomon Islands) to work as a missionary and teacher in Sinapa. They lived together on Sinapa Mission station until 1911, when they were transferred to Wanigela station. ${ }^{6}$

Today, Sara and Samuel's descendants are living in the Maisin villages of Konyasi and Uiaku, and in the Wanigela villages of Collingwood Bay. Their version of Manua's conversion is somewhat different from Newton's story. Sara's grandson Kingston Imani (from Konyasi village) told me that Manua was sent to Dogura to learn how to be a "house-girl" for the missionaries. It was there that she met Samuel. When returning to Sinapa village, the two met again and married. Whether Manua was sent to Dogura to be trained and converted as a "housegirl" for the missionaries or as a "house-wife" for the Pacific Island missionary remains unclear. However, it seems likely she was to become both, since being a house-girl in the missionary's house was often an introit to becoming the Christian wife of a male convert. What becomes clear from both accounts is that Manua underwent not only a spiritual conversion, but also, crucially, a bodily transformation. As elsewhere, the regulation of indigenous women's bodies became the focus of missionary (and colonial) civilising missions. ${ }^{7}$ Importantly, this regulation involved not just the physical body, but the alteration of various gendered bodily practices and adornments.

Newton's description of Sara reveals how her tapa cloth, necklaces and armlets were gradually removed from her body as her spiritual transformation took place. Among the Maisin, loincloths for both men and women are made by women from beaten strips of tree bark (barkcloth), or tapa, as it is locally called in English. The tapa, decorated with black and red clan designs, together with particular types of necklaces, feathers and other ornaments, visualise and materialise a clan's ancestral history and ownership of land. During a person's life cycle history, these clan regalia are ritually given, and removed, establishing not only a person's clan identity, but also his or her social status. ${ }^{8}$

\footnotetext{
5 John Barker, "An outpost in Papua: Anglican missionaries and Melanesian teachers among the Maisin, 1902-1934," in Indigenous Peoples and Religious Change, ed. Peggy Brock, Leiden: Brill, 2005, pp. 79-106, p. 96. 6 Wanigela is a cluster of non-Maisin villages, relatively close to the Maisin villages of Uiaku and Ganjiga.

7 Tony Ballantyne and Antoinette Burton, "Postscript: bodies, genders, empires: reimagining world histories," in Bodies in Contact. Rethinking Colonial Encounters in World History, ed. Tony Ballantyne and Antoinette Burton, Durham and London: Duke University, 2005, pp. 404-23, p. 406.

8 Anna-Karina Hermkens, "The gendered performance of cloth, ritual and belief," in Religion and Material Culture: The Matter of Belief, ed. David Morgan, London and New York: Routledge, 2010, pp. 231-46; Anna-Karina Hermkens, Engendering Objects. Dynamics of Barkcloth and Gender among the Maisin of Papua New Guinea, Leiden: Sidestone Press, 2013.
} 


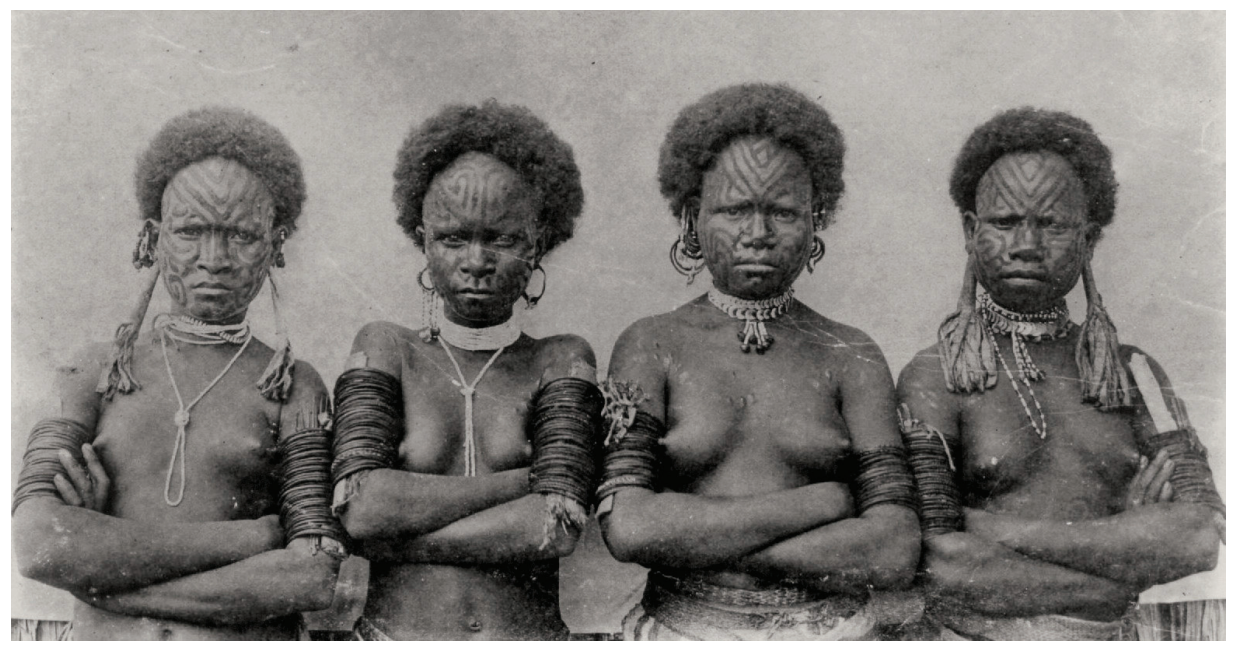

Figure 33. Uiaku schoolgirls, showing their facial tattoos. Notice the shaved foreheads and eyebrows, indicating these girls had just received their tattoo. They all wear coconut armlets, short necklaces (kokindi), short earrings (kauna) and long earrings (buoro). Unfortunately, their tapa loincloths (embobi) are less visible

Source: P.J. Money, 1908. Courtesy of the Australian Museum AMS 328, Percy Money Photographs V2649.

For Maisin people, gender and social identity is not self-evident but an "attribute which must be made known," ${ }^{\prime 9}$ predominantly through various performances, such as exchanges, festivities and life-cycle rituals, in which the decorated body is displayed..$^{10}$ Identity is thus dramatically constructed and constituted through things worn or inscribed on the body, such as barkcloth and necklaces. Cloth and necklaces embody beliefs and values about gender relations and identity, mediating relations between the individual and the social. As such, the wearing and corporeal experience of these regalia is not superficial, or restricted to the outer skin. They work "deeply into the bone," as Ronald Grimes says about life-cycle rituals. ${ }^{11}$ They have the ability to transform people's identity and their

9 Marilyn Strathern, The Gender of the Gift. Problems with Women and Problems with Society in Melanesia, Berkeley: University of California Press, 1988; Cecilia Busby, "Permeable and partible persons: gender and body in South India and Melanesia," Journal of the Royal Anthropological Institute 3 (1997): 261-78, p. 271.

10 Maisin do not divide the internal body up into different gendered parts, as has been argued for Melanesian societies in general by, for example: Bruce Knauft, "Bodily images in Melanesia: cultural substances and natural metaphors," in Fragments for a History of the Human Body: Part Three, ed. Michel Feher, Ramona Naddaff and Nadia Tazi, New York: Urzone, 1989, pp. 198-279, p. 206; Busby, “Permeable and partible persons," p. 270. The internal constitution of Maisin bodies is mixed, but not to the extent that the body contains both female and male parts, which would allow "a conceptualisation of the person as non-gendered, or rather in Marilyn Strathern's terms, as cross-sex." See Busby, "Permeable and partible persons," p. 271.

11 Ronald L. Grimes, Deeply into the Bone. Re-Inventing Rites of Passage, Berkeley: University of California Press. 2000. 
social relations, and even determine people's physiology. ${ }^{12}$ So for Manua, the removal of her regalia and her transformation into Sara, was very much akin to the experience of Maisin life-cycle rituals in which a person's new identity is signified by the removal of "old" regalia, and the dressing up of the body in a "new" one.

While Newton was not very interested in Sara's indigenous dress, which he describes and discards as a dirty and awkward thing, his colleagues and other colonial agents were extremely interested in tapa and ornaments. ${ }^{13}$ They eagerly collected these objects as "curios," providing information about the people they tried to pacify, convert, educate, make business with and, most of all, understand.

In this chapter I show the relationships between colonialism and objects such as tapa. I describe the localised and subjective character of colonialism as practised by the British Colonial Government and the Anglican Mission in particular. I elaborate on this localised process of colonialism by describing how missionarycollecting activities were related to their efforts to pacify and convert the peoples of Collingwood Bay. In addition, I show how Anglican missionaries, but also South Sea islander teachers like Samuel, who were a crucial part of the missionary project, tried to regulate and discipline women's bodies by attempting to control their sexuality, punish "sinful" behaviour by removing women's personal adornments, and change female mourning and initiation practices. This elucidates the importance of both objects and gender in colonial encounters and practices, but foremost, it shows how unwritten histories of gender, and in particular colonial histories, can be recovered from oblivion. As other studies have shown, histories of gender can be discerned and explored by unravelling their hidden threads in colonial documents, missionary reports, personal letters and novels. Here, as elsewhere, ${ }^{14}$ I want to emphasise unwritten but equally materialised traces of history, such as photographs and objects. ${ }^{15} \mathrm{In}$ particular, I focus on objects worn on women's bodies and the various stories these reveal. ${ }^{16}$

12 Hildi Hendrickson (ed.), Clothing and Difference. Embodied Identities in Colonial and Postcolonial Africa, Durham and London: Duke University Press, 1996.

13 The term "agent" is used to suggest that people could "surpass the political boundaries that ruled the encounters" contrary to what Susanne Legêne proclaims in: "Nobody's objects: early-19th century ethnographical collections and the formation of imperialist attitudes and feelings," Etnofoor 9(1) (1998): 21-39, p. 35. Moreover, indigenous people also worked as colonial agents.

14 Anna-Karina Hermkens, "Gendered objects. Embodiments of colonial collecting in Dutch New Guinea," Journal of Pacific History 42(1) (2007): 1-20.

15 Elizabeth Edwards, "Surveying culture: photography, collecting and material culture in British New Guinea, 1898," in Hunting the Gatherers. Ethnographic Collectors, Agents and Agency in Melanesia, 1870s-1930s, ed. Michael O'Hanlon and Robert L. Welsch, New York, Oxford: Berghahn Books, 2000, pp. 103-26.

16 In Hermkens, "Gendered objects," I focus on objects made by Papuan women - in particular a type of barkcloth, called maro. These cloths were and are still being produced in the Humboldt Bay and Lake Sentani area in Papua, a former colony of the Netherlands and now the easternmost province of Indonesia. 


\section{The Anglican mission: Missionisation through exchange ${ }^{17}$}

In 1890, the first missionary of the Church of England in New Guinea, Alfred MacLaren, accompanied British administrator Sir William MacGregor ${ }^{18}$ on his first trip into Collingwood Bay. ${ }^{19}$ During this trip, MacLaren was not only introduced to the inhabitants of British New Guinea, but also to the area of Christianisation that MacGregor had appointed for the Church of England. It was MacGregor's view that missions contributed to the pacification of the colony by preventing intertribal war and reducing the frequency of homicide, making the work of magistrates and policemen lighter. ${ }^{20}$ In addition, he relied upon missionaries to establish schools and basic health care, which the state was not able to provide. ${ }^{21}$ MacGregor allocated the northeast coast of Papua, which runs from Cape Ducie in Milne Bay to Mitre Rock near the German boundary, to the Anglicans. The Anglicans divided this coastline into three divisions and areas of extension, of which the second division ran from Cape Vogel to Cape Nelson, being Collingwood Bay (Map 2).

MacGregor advised that the Anglican Mission station would be most suitable in Dogura, a flattened hilltop site in Goodenough Bay, from which the missionisation of the northeast coast could be tackled. But, soon after the first buildings were completed, MacLaren died from fever. And it was Copland King who became the first missionary to be put in charge of this district. He tried to continue the work of MacLaren and extend the influence of the Anglican Church along the northeast coast. In 1892, almost a year after MacLaren's death, Copland King became head of the Mission in Dogura. ${ }^{22}$ He made several expeditions, trying to implement law and order by preventing raids in the nearby area. In 1893 and 1895, he made two exploratory trips along the northeast coast, visiting amongst other places Collingwood Bay.

17 John Barker has made extensive analyses of the impact of the Anglican Mission in Collingwood Bay, and the Maisin in particular, by focusing on the interactions and dialogues that took place between missionaries and Maisin. This paper does not seek to replicate this work but, instead, focuses on the contexts and motives of colonial collecting activities.

18 From 1888 till 1895, Sir William MacGregor (1846-1919) acted as administrator to become a lieutenant governor in 1895. Two years later he resigned and left New Guinea. He was succeeded by George Ruthven Le Hunte (1852-1925), acting as lieutenant governor between 1899 and 1903. See Sir Hubert Murray, Papua or British New Guinea, London: T. Fisher Unwin, 1912, p. 87. In 1910, MacGregor became governor of Queensland, Australia, and remained there until he retired in 1914. He died in Aberdeen, Scotland, in 1919. 19 William MacGregor, "Introduction," to F.M. Synge (author), Albert MacLaren. A Pioneer Missionary in New Guinea, Westminister: Society for the Propagation of the Gospel/University of Aberdeen Press, 1908, pp. ix-xxi, p. xi.

20 Sir William MacGregor, British New Guinea. Country and People, London: John Murray, 1897, p. 92.

21 John Dademo Waiko, A Short History of Papua New Guinea, Melbourne: Oxford University Press, [1993] 2001, p. 34; MacGregor, British New Guinea, p. 92.

22 Arthur Kent Chignell, Twenty-one Years in Papua: A History of the English Church Mission in New Guinea (1891-1912), London: A.R. Mowbray, Milwaukee: Young Churchman, 1913; pp. 34-35; J.W.S. Tomlin, Awakening. A History of the New Guinea Mission, London: Fulham Palace, 1951, p. 37. 


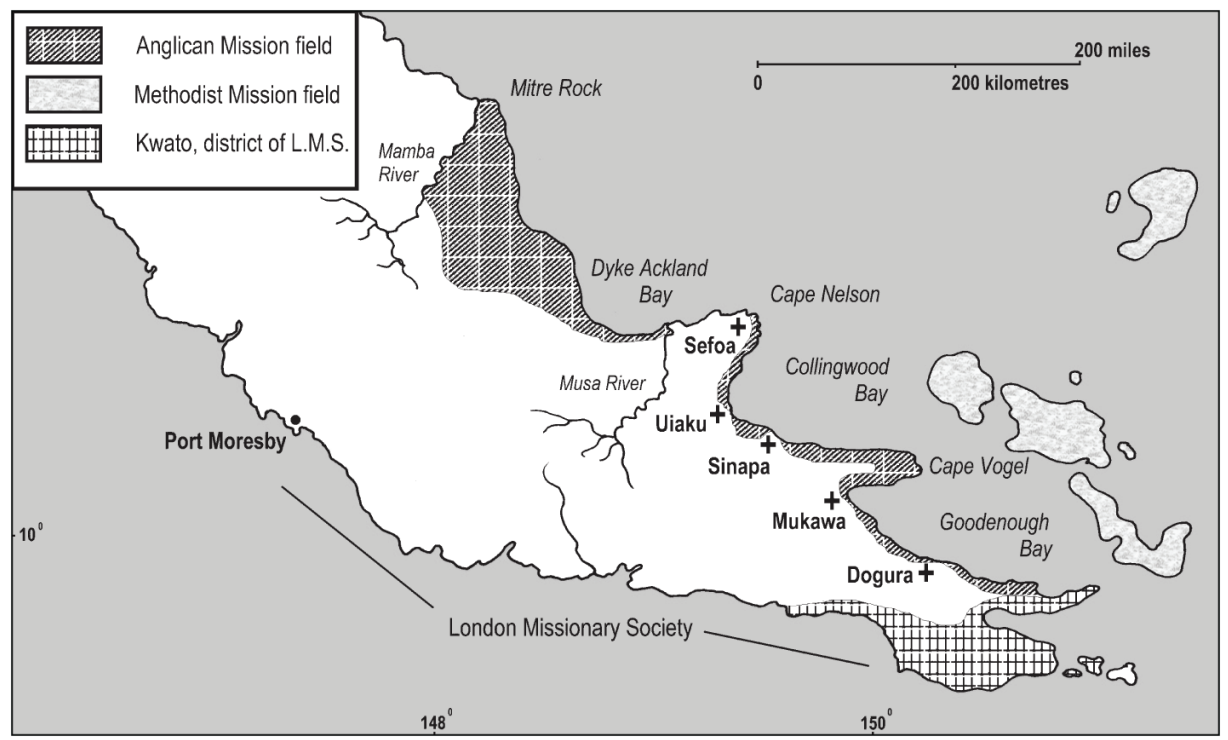

Map 2. Mission fields in the south and northeast coast of British New Guinea. The Kwato district was part of the London Missionary Society (L.M.S)

Source: David Wetherell, Reluctant Mission: the Anglican Church in Papua New Guinea, 1891-1942, St. Lucia: University Of Queensland Press, 1977, p. 331.

During these trips, King, who was probably encouraged by MacGregor's drive to collect as much as possible "before it has become too late," 23 exchanged Western goods for indigenous artefacts with Maisin and other Collingwood Bay people. As King had found out, the exchange of things was a prerequisite for establishing relationships with the Papuans. In July 1895, King wrote:

It was an adventurous and exciting trip. We examined the coast carefully, and landed wherever we could find villages. At Uiaku [the largest of ten Maisin villages] the excitement of the natives was intense. They waded into the water to meet the dinghy, and kept up a continuous roar of greeting. My boys, who landed with me, thought their time had come; but the natives were only shouting vigorously for iron, in the form of plane irons of which I had taken care to bring a good stock; and when they got me on shore they would not let me off again until I had exhausted the trade bag. ${ }^{24}$

23 Michael Quinnell, “'Before it has become too late': the making and repatriation of Sir William MacGregor's official collection from British New Guinea," in Hunting the Gatherers, ed. Michael O'Hanlon and Robert L. Welsch, New York, Oxford: Berghahn Books, 2000, pp. 81-102.

24 Chignell, Twenty-one Years in Papua, pp. 90-91. 
In Wanigela, King experienced a similar desire for iron and trade. He was not allowed into the stockaded village because he had no iron to trade with. ${ }^{25}$ "As the Wanigela men told him, a man without trade was no better than a dead man." 26

In October 1896, King visited Collingwood Bay once more, this time to explore the site MacGregor had chosen for the next Anglican mission station, Sinapa village. During this visit King and his colleague Clark met the elaborately dressed chief Wanigera. The missionary party and Maisin people engaged in exchanges, but Wanigera left the trading to his followers since he considered it beneath his dignity "to trade himself." ${ }^{27}$ Subsequently the party visited Uiaku, much to the pleasure of chief Wanigera, where they again traded with the local Maisin people, spending quite some time buying "curios." ${ }^{28}$

Although King appeared to be satisfied with the spot chosen in Sinapa village, it would take two more years before the actual building started. In order to get funding for the Collingwood Bay extension, King had to go to Australia to collect money. The results were very poor, but since the Roman Catholic missionaries equally fancied Collingwood Bay, and MacGregor again requested information on the Church's proceedings, the Anglicans, although having few financial resources, were urged to make haste with their extension. In 1897, King travelled to Sinapa, but he declined this new mission post only a few days after his arrival. He was succeeded by Wilfred H. Abbot, a high-spirited and somewhat extravagant missionary who had graduated from Oxford. ${ }^{29}$ Having arrived just a few months earlier in Papua together with the new Bishop Montagu John StoneWigg, ${ }^{30}$ Abbot became the first missionary to stay in Collingwood Bay.

\section{Wilfred Abbot (1898-1900)}

When Abbot travelled from Dogura to Sinapa to continue his predecessor's work, things were not as Abbot had expected. He found the mission house far from finished; only the pole holes had been dug. The earlier party, that was supposed to have built the mission house, suffered from fever, ulcers and depression due to the unhealthy and gloomy circumstances. It appeared to be

\footnotetext{
25 Ibid., p. 91.

26 David Wetherell, Reluctant Mission: The Anglican Church in Papua New Guinea, 1891-1942, St. Lucia: University of Queensland Press, 1977, p. 32.

27 Chignell, Twenty-one years in Papua, pp. 94-95.

28 Ibid., p. 96. It is not known what kind of "curios" Clark managed to obtain in exchange for iron, beads and items like a looking-glass, nor is it clear what happened to the artefacts King and Clark collected.

29 Chignell, Twenty-one Years in Papua, p. 99.

30 Tomlin, Awakening, p. 50; Wetherell, Reluctant Mission, p. 67.
} 
impossible to build a house in Sinapa because the soil was too swampy, and the reluctance of local people to help the laymen contributed to the sense of desolation and misery.

Abbot immediately took charge of both the situation and the Sinapa villagers. Despite the fact that all holes were filled with water and the foundations felt like mud instead of sand, Abbot persisted in getting the mission house built, arguing that "Sir William MacGregor had chosen the site for us, and he must be right." ${ }^{31}$ By promising a Sinapa chief a nice present "if he made the people do what they were told," Abbot obtained local labourers. And by shouting at the workers in the few Maisin words he had picked up, he kept them at work. According to Abbot, this shouting was exhausting, but the Sinapa people were also encouraged to provide work because they were given tobacco in exchange.

After literally having driven the Sinapa people into "Church," Abbot performed the first service among Maisin in his surplice and his "gaudy Oxford hood," which, according to Abbot, conferred a magical effect. "They probably thought I was an extra special wizard, and a very subdued 'sh-sh-sh' went through the crowd." 32 The Sinapa people had had a few previous brief encounters with white people, but were now faced with a man who compelled them into exhausting, day-filling labour and strange rituals. Although Abbot is described as an unconventional man whose eccentricities appealed to the laughter-loving side of the local people, ${ }^{33}$ the Maisin people were not very charmed by "Mad Abbot," as he was later described by his fellow colleagues. ${ }^{34}$ Sometime after Abbot had left Collingwood Bay, Maisin people confessed to Abbot's successor, Percy John Money, that they had been on the verge of killing Abbot and his mission party. Luckily for Abbot and his team, a Uiaku war leader averted the planned ambush at the last moment, by refusing to give the signal for his men to attack. ${ }^{35}$ As John Barker suggests, this Uiaku chief was probably chief Wanigera, the elaborately decorated man with whom Copland King had made friends one year earlier.

Despite Abbot's confidence in Sinapa and the efforts of the local people in building Abbot's mission house, it proved to be impossible. Consequently, Stone-Wigg decided to establish a station at Wanigela. ${ }^{36}$ Initially, the Uiaku chief Wanigera invited the missionaries to set up a station at Uiaku, but because the other men of his tribe objected, the missionaries decided to move to Wanigela

31 Chignell, Twenty-one years in Papua, p. 103.

32 Ibid., p. 105.

33 Tomlin, Awakening, p. 50.

34 Wetherell, Reluctant Mission, p. 68.

35 John Barker, "Cheerful pragmatists: Anglican missionaries among the Maisin of Collingwood Bay, Northeastern Papua, 1898-1920," The Journal of Pacific History 22(2) (1987): 66-81, p. 72.

36 Chignell, Twenty-one Years in Papua, p. 106. 
instead. ${ }^{37}$ From 1898 till December 1900, Abbot "ruled" Wanigela. Continuing his Sinapa regime of "clearing grounds" and "managing" people by threatening them verbally and physically, Abbot got "the best out of the native labourers while the Mission Station at Wanigela was being built." ${ }^{\prime 38}$

Abbot highly valued paternalist ethics, sexual morality and celibacy. He punished those who had "fallen into sin," but he also tried to protect the local girls from being sexually abused by both South Sea islanders and white men, including those affiliated with the Government station at Tufi. ${ }^{39}$ Abbot's regime ended when he resigned after getting into trouble with the Bishop. Abbot was blamed for harassing his assistant, South Seas islander James Nogar, after suspecting him of having violated his state of celibacy, which was denied by the latter. ${ }^{40} \mathrm{He}$ had also ordered a large quantity of rum, as well as trade goods (amongst others axes and metal) from the Burns Philp merchants in Samarai. ${ }^{41}$ Abbot felt the Bishop had misinterpreted his actions and the Burns Philp order, as he intended to use the liquor as a tonic only, while the goods were meant for trade with the local people. ${ }^{42}$ Abbot did not leave Papua New Guinea empty handed. When he returned to London he had with him a considerable collection of Collingwood Bay artefacts, which he sold to the British Museum, as well as to the Horniman Museum in London, the Pitt-Rivers Museum in Oxford and the Cambridge Museum of Archaeology and Anthropology.

As an Oxford Master of Arts, Abbot must have had a particular way of perceiving the value of the artefacts made by Wanigela and Maisin people. According to his writings to the British Museum authorities, he had been collecting during his entire three-year stay in Collingwood Bay. It is not known how many objects Abbot actually did collect and subsequently offered to the various museums in England, but the British Museum bought 131 items in 1901. ${ }^{43}$ Among these items are thirteen pieces of decorated barkcloth attributed to Collingwood Bay. Although Abbot seems to have engaged in collecting artefacts less seriously than MacGregor, he was rather determined to sell his collection. Just a few months before Abbot resigned, his mother, to whom he had sent some of his collection, offered them to the British Museum. "My son the Rev. W.H. Abbot who is doing pioneer mission work under the Bishop on the N[orth] Coast of

\footnotetext{
37 Ibid., p. 107. Soon after, Doriri raided Uiaku and killed fifteen people, including the mission-favouring chief, Wanigera.

38 Tomlin, Awakening, pp. 50-51.

39 Wetherell, Reluctant Mission, pp. 246-50.

40 James Nogar to the Bishop, Wanigela, March 18, 1901, Anglican Archives, Port Moresby, Box 22, file 4.

41 Wetherell, Reluctant Mission, pp. 67, 109.

42 Wilfred H. Abbot, Collingwood Bay, to the Bishop, London, Anglican Archives, Port Moresby, Box 20, file 1 .

43 Although some of Abbot's artefacts have limited information on their particular use, the majority are almost entirely without any provenance or ethnographic information. Abbot's failure to document any details of his artefacts becomes especially salient when one compares them with the collection of his successor Percy Money.
} 
British New Guinea has sent home some curious bones \& implements of the Cannibals there, \& also fine specimen head-dresses in feathers." ${ }^{\prime 4} \mathrm{~A}$ few months after his resignation and return to London, Abbot recommended to the museum that they acquire his collection. He sounds rather desperate and urges the museum to make a good offer as he writes:

I do hope the Museum authorities will take these facts into consideration when making their offer: That I have waited to allow them first pick out of my curios that they are taking all the plums-leaving the poorer specimens on my hands. That I was the first white settler in the Bay \& that I have been collecting for three years in the Bay. That I have not yet sold or given away a single article. That several of the clubs especially the white \& the knobbly one are the only specimens I have ever seen. That they are the result of three years collecting, on the spot. ${ }^{45}$

A year earlier, the museum had received a donation by Lieutenant-Governor R.G. Le Hunte that consisted of three artefacts collected by Abbot in Collingwood Bay. So apparently, despite his protestations, Abbot did sell or give his collected artefacts to other people. Le Hunte, who was MacGregor's successor from 1898 till 1903, approved of the mission and acknowledged their work and importance for the government. ${ }^{46}$ Abbot in turn, clearly identified with the colonial administration and its representatives, as he had promised Le Hunte to erect government buildings on Tuf, which eventuated through the intervention of James Nogar, who persuaded the local population to cooperate and build the station. ${ }^{47}$ Abbot's gift to Le Hunte seems to embody this intimate relationship between mission and government.

\section{James Nogar (1898-1906)}

Abbot did not rebuild and convert Wanigela on his own. He was assisted by an energetic and ambitious young man from the New Hebrides, named James (Jimmy) Nogar. Islanders from Melanesia, such as James Nogar and Samuel Siru (from Solomon Islands), were the first missionaries to live permanently amongst Maisin. David Wetherell, in his article on Queensland Melanesians in New Guinea, calls Nogar "The Exemplar," as Nogar seems to have been "extremely well fitted for interpreting Christianity to village people." ${ }^{48}$

\footnotetext{
44 Henrietta Abbot, England, to the British Museum, London, 1900, Anglican Archives, Port Moresby.

45 Wilfred H. Abbot, Collingwood Bay, to the British Museum, London, 1901. Anglican Archives, Port Moresby.

46 Tomlin, Awakening, p. 51

47 David Wetherell, “'The bridegroom cometh': the lives and deaths of Queensland Melanesians in New Guinea, 1893-1956," Pacific Studies 12(3) (1989): 53-89, p. 61.

48 Ibid., pp. 60-63. The New Hebrides is now independent Vanuatu.
} 
Nogar, born in 1876 at Sonamlo, Tanna Island, had been working as a young boy at the Tweed River fields south of Brisbane, which had imported labourers from the New Hebrides and Solomon Islands to work on its sugar plantations. ${ }^{49}$ When an Anglican parson offered Nogar a position, he accepted, becoming the supervisor of islander scholars at St. Barnabas' School in Bungalore. This school, and others, had been set up to minister to the plantation labourers, preparing them for baptism and providing a rudimentary education. ${ }^{50}$ In order to fulfill his new position, Nogar was baptised and received Anglican confirmation, thereby renouncing his father's Presbyterian connection. ${ }^{51}$ Nogar's life took an even more drastic change after proposing marriage to a young white lady who was part of the church choir. The sugar planters were resentful of Nogar's audacity and turned his fellow labourers against him, upon which St. Barnabas' School emptied. Opting to work in a more productive field, Nogar accompanied StoneWigg to New Guinea, teaming up with Abbot in Wanigela. ${ }^{52}$

It seemed that Nogar copied Abbot's vigorous handling of the Wanigela people. As Abbot wrote, "[James] has quite adopted my methods of dealing with unruly natives, ${ }^{153}$ which reflects their shared belief in using physical punishment when deemed necessary. In 1904, Nogar went (at least once) too far, severely thrashing a Wanigela girl, who died the day after. The mission held an inquiry about her death, but since the girl's father attributed her death to sorcery, Nogar got away with the assault and was only reprimanded by the mission. ${ }^{54}$ Obviously, the white missionaries who were responsible for overseeing the work of "native" teachers like Nogar were not reprimanded, nor were their punitive actions critiqued.

Abbot's and Nogar's influence in local village life was clearly felt by some of the arrangements and rules Abbot introduced. They built a church and a school, which was attended by young male boarders who stayed at the mission station and village boys. Attendance was soon made compulsory day and night. The boys were instructed in the morning, after which the boarders were put to work on the station, and their fathers, after having done their hunting and fishing, were instructed in the evening. ${ }^{55}$ The village layout was changed from

\footnotetext{
49 The total number of Pacific labourers resident in Queensland and the Tweed River district of New South Wales is estimated to have been 6,389. See Clive Moore, "'Good-bye, Queensland, good-bye, white Australia; good-bye Christians': Australia's South Sea islander community and deportation, 1901-1908," The New Federalist (4) (2000): 22-29, n33; and Dorothy Shineberg, The People Trade: Pacific Island Labourers and New Caledonia, 1865-1930, Honolulu: University of Hawai'i Press, 1999.

50 Barker, “An outpost in Papua," p. 90.

51 Wetherell, "“The bridegroom cometh,"' p. 60.

52 Ibid

53 Ibid., p. 61.

54 Ibid., p. 62.

55 Chignell, Twenty-one Years in Papua, p. 110; Wetherell, Reluctant Mission, p. 107.
} 
traditional patterns into rows of houses, and a crude form of currency was introduced. ${ }^{56}$ Furthermore, churchgoing was made compulsory for the men, and adultery was prohibited. ${ }^{57}$

In addition, an Anglican business network was established facilitating the trade and circulation of ethnographic artefacts, which, of course, meant an extra income for the entrepreneurs involved. It appears that especially Nogar was involved with the collecting and selling of "curios." By 1899, Nogar was conducting a flourishing trade in Maisin, and probably artefacts from other coastal regions, exchanging them for tobacco, axes and other trade-store goods, and selling them at $£ 2.10$ each, with a cut rate of $£ 1.10$ to trading partners. ${ }^{58}$

After Abbot had resigned in December 1900, Nogar seems to have been in charge of the Wanigela mission. When Abbot's successor Percy Money arrived, Nogar was conducting the largest school in the mission, made up of seventy children and seventeen boarders, who as observed by Lieutenant Governor Le Hunte, "sang a hymn in their own language with their arms folded" (see Figure 33)..$^{59}$ As Le Hunte stated in his Government report, written six days after Percy Money's arrival. "There is a striking difference between the faces of the mission-taught children and those of other places such as Uiaku [which didn't have a mission station yet]. They look as if they had no more knowledge of savagery or fighting than village children in our own country, yet it is still almost at their doors." ${ }^{60}$

In August 1901, Nogar applied for a lay reader's licence, arguing he would "knowingly teach nothing contrary to the Doctrine of the Church of England as contained in the Thirty-nine articles." ${ }^{\prime 61}$ And indeed, Nogar made a long-lasting impression in Wanigela and beyond, making "a major contribution toward the planting of mission Christianity in Collingwood Bay." ${ }^{22}$ In 1903, he married Mary Maniarun, from Kumarbun village of Wanigela who, like Sara, had been trained to be a proper housewife at the headquarters of the Anglican mission in Dogura. James and Mary would have at least one son, named Japhet. By marrying a local woman, Nogar became very much part of the local community. His acceptance and popularity is evident because when he died of fever in 1906,

\footnotetext{
56 Barker, “'Cheerful Pragmatists,'” p. 72.

57 Wetherell, Reluctant Mission, p. 67.

58 James Nogar, Wanigela, to Mr. Johnson, "Concerning curios business," August 23, 1899, Anglican Archives, Port Moresby: Box 22, file 4. James Nogar, Wanigela, to Mr. Johnson, "Concerning curios business," August 24, 1899, Anglican Archives, Port Moresby: Box 22, file 4; Wetherell, “'The bridegroom cometh,'” p. 61. 59 Wetherell, "'The bridegroom cometh,"' p. 62; The posture of the children, sitting or as pictured in Figure 33, standing with their arms folded, may represent the success of the mission in having "domesticated" and converted them, the folded arms signalling respect. But the facial and bodily expression of the girls in Figure 33 seems to counter this interpretation, as they very much seem to contest and challenge the photographer, missionary P.J. Money.

60 Tomlin, Awakening, p. 51.

61 Wetherell, "“The bridegroom cometh,"” p. 61.

62 Ibid., p. 63.
} 
he was buried in the midst of "the greatest lamentation and mourning from the whole population." ${ }^{63}$ According to Wetherell, Stone-Wigg's epitaph for Nogar sums up the Anglican ideal for the Pacific islander teacher: "A herald of the Gospel, simple, unlearned, faithful unto death." ${ }^{\prime 64}$

\section{Percy John Money (1901-1910)}

In June 1901, when Money took charge of Wanigela Mission Station, the village had become "one of the best organised and most prosperous communities on the north Papuan coast." ${ }^{65}$ Money's orders from the Bishop were to consolidate this good work at Wanigela and to open a new station among the Maisin in Uiaku. ${ }^{66}$ In this way, the influence and civilisation of the Anglican Mission could be extended among the most unruly and "stubbornly heathen population" of the area, the Maisin (see Figure 34). ${ }^{67}$

Despite the fact that the leaders of Uiaku had rejected the Anglicans after their debacle in Sinapa and subsequently refused the mission's periodic offer of teachers, ${ }^{68}$ they agreed with Money's offer to build a church and subsequently a school in Uiaku (the building commenced in 1902). This acceptance was perhaps due to their experience with the government in December 1900, when during a punitive expedition led by C.A.W. Monckton, three Maisin men were killed. ${ }^{69}$ This act of force and violence against Maisin people, which coincided with a general increase of government activities in the area, likely convinced Maisin to cooperate with the mission. ${ }^{70}$ The newly built government station in Tufi was permanently occupied and ruled by the Resident Magistrate and his constables, intensifying colonial influence and activities. Nevertheless, Maisin people gave Money a hard time as he wrote in a letter to Stone-Wigg, "You do not know what we had to put up with and fight against the first 18 months at Uiaku; the people were overbearing and annoying, they would hardly do a hands turn for us and I thought myself extremely fortunate in getting what I did done." ${ }^{71}$

As a young Australian layman and a former "boxer, football coach, winner of bicycle races, and performer on the parallel bar," Money represented the manly

\footnotetext{
63 Ibid.

64 Ibid.

65 Wetherell, Reluctant Mission, p. 106.

66 Barker, "'Cheerful pragmatists,'” p. 73.

67 New Guinea Mission 1902, Annual Report 1901-1902, Sydney, p.33.

68 Barker, "“Cheerful pragmatists,"” p. 73.

69 C.A.W. Monckton, Taming New Guinea, New York: Dodd Mead and Company, 1927, p. 173.

70 Personal comment, John Barker, May 2013.

71 Percy John Money, Wanigela, to the Bishop. August 21, 1905, Anglican Archives, Port Moresby, Box 21, file 23. Money complains that Maisin refused to help him in any way with setting up a Mission Station in Uiaku.
} 
vigour of the mission. ${ }^{72} \mathrm{He}$ was not only in the prime of his life and in good shape, he also had the capacity to act not only as evangelist, but also as "teacher, architect, carpenter, translator, journalist, photographer" and archaeologist. ${ }^{73}$ In contrast to his predecessor Abbot, Money seemed to be a rather sympathetic and easygoing missionary. Instead of bullying the local people or using force, he actually worked with them and used his wits and charms to keep them motivated. At one point in time, probably after his retirement and apparently in the back garden of his Australian home,${ }^{74}$ he even dressed up as a native and had himself photographed, an act of mimicry that both demonstrates his fascination for native life as well as the distance between the two cultures.

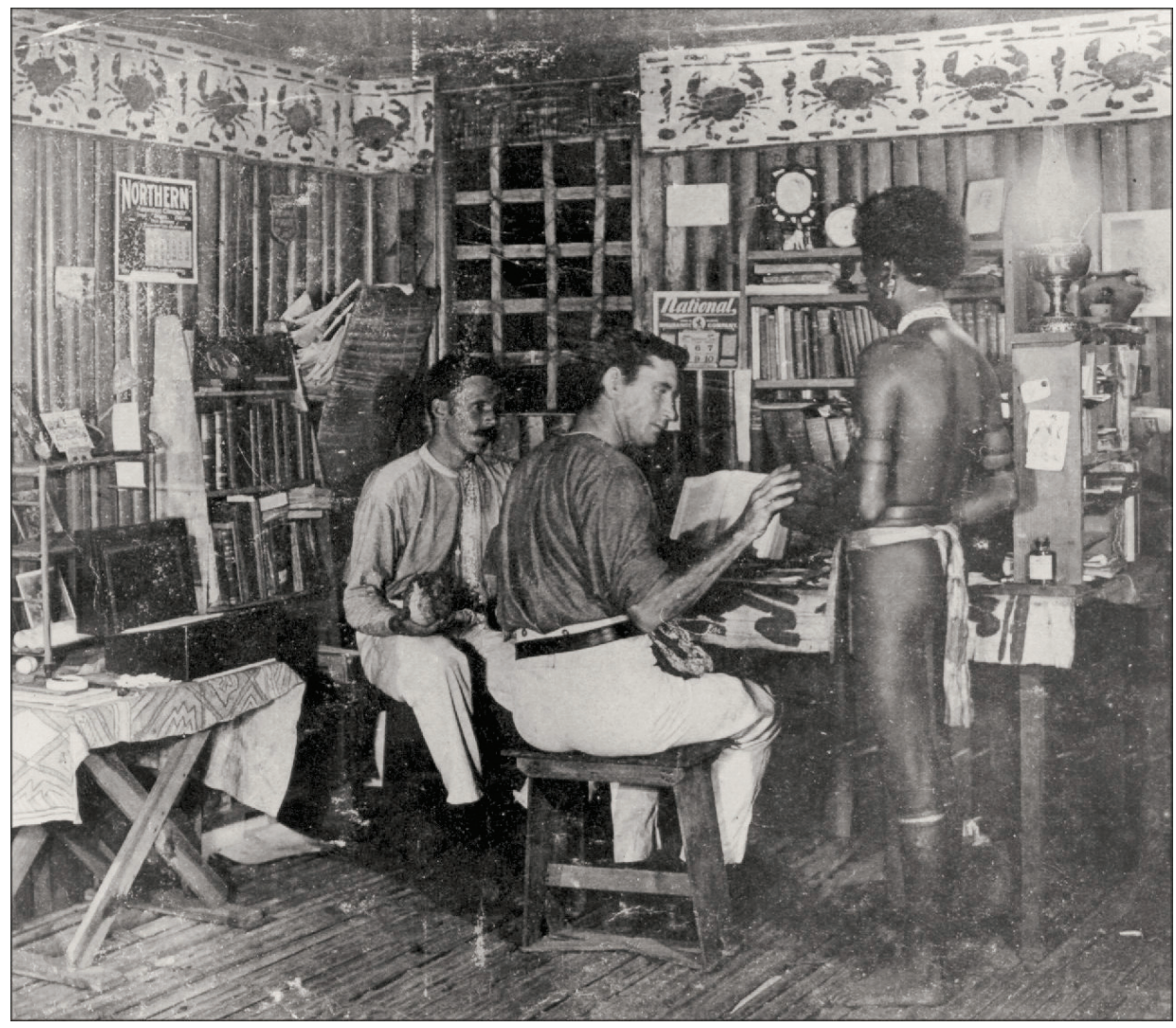

Figure 34. Money in "The Den," the Uiaku missionary house. Notice the use of indigenous designed tapa cloth as a tablecloth and Westerndesigned strips of tapa cloth as a frieze

Source: P.J. Money, 1902: “The Den, taken by flashlight." Courtesy of the Australian Museum, AMS 328, Percy Money Photographs, M2066/1.

72 Wetherell, Reluctant Mission, p. 59.

73 Barker, "'Cheerful pragmatists,'" p. 73.

74 Personal comment, John Barker, 23 May 2013. 
However, Money's fascination and patience with regard to local customs did not extend to all spheres of Maisin life. Money lamented the "atmosphere of fornication" in Uiaku village, and strongly opposed adultery, widow mutilation, magic and sorcery. ${ }^{75}$ But at the same time he also seems to have admired people's firm beliefs. After a suspected sorcery attack, he reflects, "Did they but believe as firmly in the True God as they do in their traditions, witchcraft and sorcery, they would indeed be noble Christians, for they live what they believe."76

Despite Money's frustrations with regard to the lack of Anglican guidance and support, his work in Uiaku seemed to have been rather successful. Statistics show that from 1903 to 1909 over a hundred students regularly attended Uiaku School, while church attendance was equally stable, as each Sunday about eighty to ninety individuals attended the service. ${ }^{77}$ Whether these statistics show an actual acceptance of Anglican practices is difficult to tell. It seems Uiaku "oscillated between upholding Christian practices when Money was present and abandoning them when he was not." ${ }^{178}$

Under Money's "rule," two additional stations in Sinapa and Okein were built, thereby increasing Anglican presence but also missionary work and travel. From 1905 until 1911, the station in Sinapa was occupied by Samuel Siru. Just like Nogar, Siru had been recruited by the mission in Queensland. By 1910, Melanesians would make up 70 percent of the Anglican staff in Papua. ${ }^{79}$ Barker notes that in comparison to the Samoans and Fijians in Protestant areas, the Melanesian teachers were very poorly educated. ${ }^{80}$ According to the Anglican leaders, this was not a big problem as the Melanesian teachers were considered to be first and foremost missionaries. As Barker summarises, "Their main duty was to provide Sunday services, pray for those in need, set a good example in their daily life and instruct all in the basic beliefs and rituals of the church." ${ }^{11}$ Samuel Siru's educational skills were also considered to be low, but he seemed to have learned Maisin easily and had attracted a large number of students. ${ }^{82}$ According to Arthur Kent Chignell, who succeeded Money in Wanigela, this

75 Percy John Money, Uiaku, to the Bishop, April 5, 1907, Anglican Archives, Port Moresby, Box 21, file 23. Money also mentions practices of infanticide and abortion, although it seems he experienced one case of infanticide only. Taking current Maisin validations of children into account, it seems that this representation of Maisin life is based upon "Western" presumptions regarding the immoral living of "heathen" people.

76 Percy John Money, Uiaku, "Notes and news from the staff," September 3, 1904, Anglican Archives, Port Moresby, Box 5, file 8 .

77 Barker, “'Cheerful pragmatists,'” p. 74.

78 Liz Bonshek, "Money, pots and patterns: the Percy Money collection of barkcloth and pottery held at the Australian Museum," M.A. thesis, Brisbane: University of Queensland, Department of Anthropology, 1989, p.19.

79 Barker, “An outpost in Papua," p. 90.

80 Ibid., p. 91.

81 Ibid., p. 92.

82 Ibid., p. 93. 
was due to the fact that he was "intensively native." ${ }^{83}$ Siru spent quite some time taking care of his home, draining the swamp and planting coconuts and large gardens, and negotiating with the elders of the Virani clan for a brideManua.$^{84}$ Eventually, Siru left the mission after complaints about his work and accusations of stealing from the mission stores. He worked for a brief period in Tufi, returning to Sinapa in 1913, where he died one or two years later. ${ }^{85}$ Sara and Samuel had two children, Simon and Mary. Only Mary, born in 1903, would survive. In 1916, the mission persuaded Sara to leave the man with whom she was then living and move to Wanigela with toddler Mary. However, Sara was brought back to Sinapa by her brother, where she remarried, leaving Mary behind at Wanigela in the missionary's care.

In the meantime, Money had a hard time supervising the growing mission in Collingwood Bay. The Uiaku and Wanigela mission logs witness to the frequency with which Money travelled by either foot or boat between Sinapa, Uiaku and Wanigela villages in particular. ${ }^{86} \mathrm{He}$ seems to have hardly spent more than one week in one place, leaving the responsibilities of teaching and preaching to Siru, and other Melanesian teachers who worked among the Maisin: Timothy Gori (from Solomon Islands who left soon after arriving in 1903), Willy Pettawa (from the New Hebrides, who died in 1907), and the brothers Ambrose Darra and Benjamin Canae (from Nggela). The brothers arrived in 1907 and would be the "official face of Christianity to the Maisin" for the following twenty years. ${ }^{87}$ Only occasionally Money would take the Sunday hearers' class and services that were held on each of the stations. In addition, Money ministered to several other scattered villages in the area. These responsibilities probably undermined Money's health. By 1903 he had suffered at least three malaria attacks and in 1905 and 1907 he was forced to leave Collingwood Bay because of serious illness. ${ }^{88}$

\section{Money's collection}

While in charge of Wanigela district, Money collected hundreds of objects for the Australian Museum. As a proto-anthropologist, he made ethnographic notes about the items he collected and the ceremonies he witnessed, often mentioning the local names in both Ubir and Maisin language. As a gifted photographer, he made various photographs of the environment, its people and their customs. His collection is therefore unique, giving an insight into the "daily" activities of Collingwood Bay life between 1903 and 1910. But someone else may have contributed to Money's collection: Annie Ker. Money and Ker married on

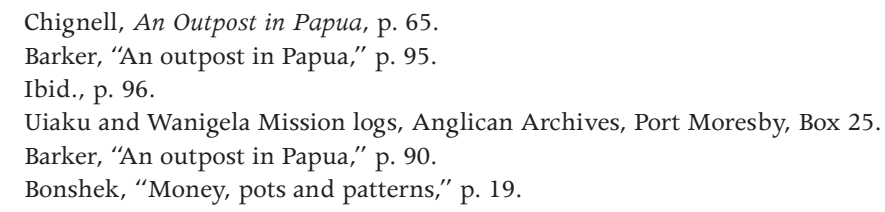


22 April 1909 in Australia, returning (albeit briefly) to Wanigela before leaving the mission in $1910 .^{89}$ It is probable that Annie Ker contributed to Money's collecting of both data and artefacts, especially since she was the first Anglican missionary to publish a book in 1910, called Papuan Fairy Tales about Wedau (Milne Bay) myths. ${ }^{90}$ Money does not refer to his wife's activities or contributions, but in 1934 she donated remnants of Money's collection to the Australian Museum. Among Collingwood Bay artefacts, there are several specimens from Wedau and the Trobiand Islands. It seems likely Annie Ker collected these objects herself while working as a missionary in Milne Bay.

Money collected foremost for the Australian Museum in Sydney, but he also collected for the Anglican Church. From 1905 onwards, Money was obliged to collect primarily for the Bishop and "his" "Mission Museum." Money was not very content with the Bishop's claim upon Money's discoveries, and felt his "wings had been clipped" but offered the Australian Museum duplicates of anything he found - an offer eagerly accepted. ${ }^{91}$ In contrast to the Bishop, who was convinced "that a collection was far more valuable in a place like this where one could study the natives at the same time," Money "thought a collection more valuable where it could be properly cared for." ${ }^{\prime \prime 2}$ But he had no other choice than to adhere to the Bishop's wishes. In a letter to Stone-Wigg he wrote:

I confess that I thought specimens were better in a public museum where they are properly cased \& cared for than in one such as ours \& therefore send better specimens to the Museum in Sydney. I still think so in spite of what the scientists say, but in future you can rely on the mission being dealt with as you suggest.... You never gave me instructions to buy for the Museum \& so I did not do so. If you will tell me what you want for the collection \& and are willing to pay what the natives want for them, I shall get them for you. ${ }^{93}$

Not all the objects Money collected went into either the Australian or the Mission Museum. Some of the artefacts collected by Money were sent to the mission depots in Port Moresby, where the mission held "curios" sales (see Figure 35). ${ }^{94}$ This sale obviously facilitated collectors of Papua New Guinean artefacts, at the same time providing some hard-needed revenue for the mission.

\footnotetext{
89 Personal comment, John Barker, 23 May 2013.

90 Annie Ker, Papuan Fairy Tales, London: Macmillan and Co. Ltd., 1910.

91 Percy John Money, Collingwood Bay, to the Australian Museum, Sydney, 1906, Australian Museum Archives, Sydney, M23/1906; Percy John Money, Collingwood Bay, to the Australian Museum, Sydney, 1906 Australian Museum Archives, Sydney, M51/1906.

92 Percy John Money, Collingwood Bay, to the Australian Museum, Sydney, 1906, Australian Museum Archives, Sydney, M51/1906.

93 The scientists Money refers to were members of "the Major Daniels expedition," who influenced Bishop Stone-Wigg to set up his own Museum. Ironically, some of them would, probably due to Money's shipments of artefacts, be able to obtain several pieces of Collingwood Bay tapa. Percy John Money, Wanigela, to the Bishop, August 21, 1905, Anglican Archives, Port Moresby, Box 21, file 23.

94 Percy John Money, Uiaku, to the Bishop, April 19, 1907, Anglican Archives, Port Moresby, Box 21, file 23.
} 


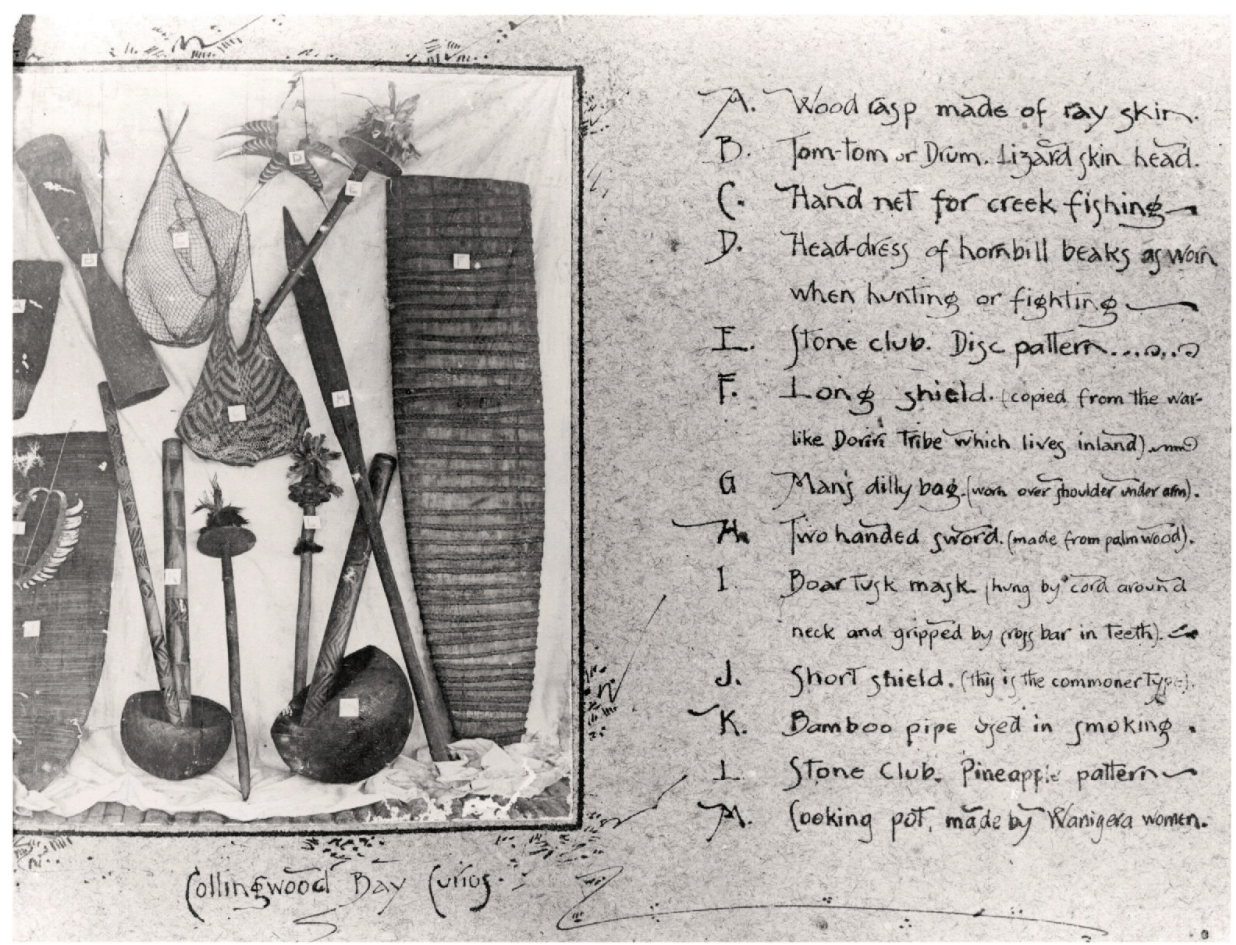

\section{Figure 35. "Collingwood Bay curios"}

Source: P.J. Money, 1902. Courtesy of the Australian Museum, AMS 328, Percy Money Photographs, M2065/7.

As a collector, Money wanted to collect specimens before it was too late. As he stated in 1904, "much that is interesting about the natives of this part may soon be lost." ${ }^{95}$ But, Money was not able to collect all the curios he wanted. In a letter to the Bishop he complained about the fact he was not able to obtain "certain of their more valuable things. They have some things which they will not part with even though you offer a fabulous price - they are heirlooms." ${ }^{\prime \prime 6}$ The heirlooms Money was talking about are pieces of clan tapa, and objects such as stone lime-sticks, particular shells and other valuables that are kept in clan elders' houses as kawo, clan emblems.

Money also made hundreds of photographs of various arts, crafts, games and customs, thereby documenting aspects of Collingwood Bay culture. He tried to sell these photographs to various museums and institutions all over the world, arguing they "are particularly valuable as they are the only ones of the kind in

95 Bonshek, “Money, pots and patterns," p. 19.

96 Percy John Money, Wanigela, to the Bishop, August 21, 1905, Anglican Archives, Port Moresby, Box 21, file 23. 
existence, and it will not be long before European influence will affect native habits. ${ }^{\prime 97}$ He did not reflect upon nor see as problematic his own role in initiating the demise of some of these customs. In fact, it seems that by documenting these objected customs, he also preserved them.

Money, for example, opposed various practices associated with mourning. But although rejecting these practices, he documented them by taking photographs and collecting objects. He accumulated some ornaments and clothes used in mourning and photographed various aspects of the life associated with being a widower or widow. These images show both men and women in various stages of mourning, wearing their matching mourning regalia. The most striking image is that of a widow completely covered with tapa, crawling on hands and knees through the sand. Another example of this paradox of collecting while denouncing is apparent in Money's collecting and, at the same time, destroying magic charms.

The mission Annual Report of 1902-03 states that Money asked if he could keep certain carved figures as "curios" when the Wanigela men decided to destroy them. The figures or charms were probably used in relation to sorcery and although the Maisin were very eager to get rid of them, their destruction was certainly triggered or encouraged by the presence of the Anglican missionary. Money received the mission's permission to keep the charms. ${ }^{98}$ In Uiaku, Money had equally been involved in the destruction of charms, which people had either thrown away, or "given to the missionaries to destroy." ${ }^{99}$ So ironically, some of these "tokens of heathen religion" were actually saved by the missionary who, either directly or indirectly, had instigated their destruction. Suzanne Legêne has labelled this the "paradox of colonial process" in which "religious symbols and systems were attacked and even destroyed on location, to reappear-out of context - in European showcases." ${ }^{100}$ One can argue that local people also took advantage of the missionary presence, letting the missionaries destroy objects that were too dangerous to deal with by, in this case, Maisin themselves. ${ }^{101}$

\footnotetext{
97 Percy John Money, Collingwood Bay, to the Australian Museum, Sydney, December 1910, Australian Museum Archives, Sydney.

98 Wetherell, Reluctant Mission, p. 177; John Barker, “Dangerous objects: changing indigenous perceptions of material culture in a Papua New Guinea society," Pacific Science 55(4) (2001): 359-75, p. 363.

99 Percy John Money, Uiaku, "Notes and news from the staff," September 18, 1906, Anglican Archives, Port Moresby, Box 5, file 8 . The charms that were collected and burned were brought together by Melanesian teacher Willy Pettewa.

100 Susanne Legêne, “Nobody's objects: early-19th century ethnographical collections and the formation of imperialist attitudes and feelings, Etnofoor 11(1) (1998): 21-39, p. 36.

101 Barker, “Dangerous Objects," pp. 359-75.
} 


\section{Colonial materialisations}

It may be argued that a focus on materiality was intrinsic to the colonial project and to its failure or success. ${ }^{102}$ As argued by Chris Gosden and Chantal Knowles, objects were crucial to colonial relationships. ${ }^{103}$ The network established by Nogar and Abbot was part of a larger colonial network and society that provided the framework for ethnographic collecting. Mission stations like Wanigela and Uiaku, and the government station in Tufi were spatial and geographical centres of white colonial rule, and, as so-called "advanced posts of civilization," essential for the work of international ethnologists. ${ }^{104}$ From the 1900s onwards, several "professional" collectors obtained Collingwood Bay artefacts through this network. Some, like Austrian ethnologist Rudolf Pöch, resided for a considerable length at the government station in Tuf. ${ }^{105}$ His "stationary" and first-hand collecting contrasts with the method applied by scientific collectors, such as Charles Gabriel Seligman (1910) and A.B. Lewis ${ }^{106}$ who engaged in more "mobile," and sometimes even second-hand ways of collecting. ${ }^{107}$

Making use of the British colonial network, Lewis travelled by steamer along routes that linked missions, government stations and mining centres. Although he collected a large number of artefacts himself, about half of his Papua collection was brought about by helpful expatriates, missionaries, and other colonial agents. ${ }^{108}$ Lewis' entire Collingwood Bay collection (a total of 388 objects, including objects from Wanigela and Uiaku) was bought from the Reverend F.W. Ramsay, ${ }^{109}$ who had obtained these artefacts from his fellow Anglican missionaries who worked there, such as Money and his successor Chignell. ${ }^{110}$

As discussed earlier, exchange was also crucial in the first interactions between the colonial government, missionaries and local people. As a matter of fact,

102 Michael Rowlands, "A materialist approach to materiality," in Materiality, ed. Daniel Miller, Durham: Duke University Press, 2005, pp. 72-87; Chris Gosden and Chantal Knowles, Collecting Colonialism. Material Culture and Colonial Change, Oxford: Berg Publishers, 2001, p. 6.

103 Gosden and Knowles, Collecting Colonialism, p. 24.

104 Michael O'Hanlon, "Introduction," in Hunting the Gatherers. Ethnographic Collectors, Agents and Agency in Melanesia, 1870s-1930s, ed. Michael O'Hanlon and Robert L. Welsch, New York, Oxford: Berghahn Books, 2000, pp. 1-31, p. 3.

105 Hermkens, Engendering Objects.

106 Seligman was a member of the Daniels expedition. During the Joseph N. Field South Pacific Expedition, which was conducted from 1909 to 1913, Lewis became the first American to conduct systematic ethnological field research in Melanesia. See Gosden and Knowles, Collecting Colonialism; and Robert Welsch, An American Anthropologist in Melanesia: A.B. Lewis and the Joseph N. Field South Pacific Expedition, 1909-1913, Two volumes, Honolulu: University of Hawai'i Press, 1998.

107 O'Hanlon, "Introduction." Lewis would not be the last "famous" traveller in the area. In 1921, Frank Hurley visited Wanigela, photographing several daily activities and people during his one-week stay.

108 Welsh, An American Anthropologist in Melanesia, p. 488.

109 Ramsay had come to Papua in 1900 and worked as a rector in Samarai, where Lewis had met him. Wetherell, Reluctant Mission, p. 80; Welsh, An American Anthropologist in Melanesia, p. 491.

110 Welsh, An American Anthropologist in Melanesia, p. 487. 
the relationships which developed between colonial agents and local men and women were based upon the exchange of services, labour, goods and locally produced artefacts. These relationships were not as unequal as one might think. Nor were they "a series of experiments" due to the lack of norms and their unpredicted outcome. ${ }^{111} \mathrm{I}$ argue that the exchanges were actually not at all experimental, at least not to the people living in Collingwood Bay.

When comparing the types of objects collected by our Collingwood Bay collectors, it becomes clear that Collingwood Bay is foremost represented in these collections by stone tools, ornaments, (prehistoric) pottery and barkcloth. ${ }^{112}$ As such, the social relationships established between government, missionary agents and Collingwood Bay people, has foremost been constituted through the exchange of these particular objects. Importantly, these objects were, and still are, part of extensive local and regional exchange networks. In fact, it seems that colonial exchange was incorporated into the local barter system, providing a context for Collingwood Bay people (and colonial collectors) in which things, ideas and images could be exchanged and appropriated. By merging colonial exchange into the "traditional" barter system, relations that for centuries had enabled Collingwood Bay people to obtain valuable goods (such as adze stones and red shell necklaces) were effectively extended. Thus, while collectors certainly had their preference for certain artefacts (MacGregor for example was very interested in stone clubs), they were very much directed in their collecting activities by the Papuans with whom they engaged in exchange. In the villages, the predominantly male collectors were subjected to Maisin agency. Maisin refused to deal with them if they did not have anything interesting to barter with, they refused to part with particular objects, such as heirlooms, refused to help colonial agents, or even thought about killing these funa fwei (white skins).

From a local perspective, the exchange of things created relationships with foreigners and their desired goods. These goods could be used locally, or enter exchange networks to obtain other objects, but they were also used in local politics as markers of status and power. The pieces of red cloth, iron and beads obtained from colonial agents in exchange for local artefacts may even have represented the "Big Chief" of Papua, MacGregor himself. Chief Wanigera from Uiaku village wore a shirt given by MacGregor's party as a status symbol. In combination with his exuberant indigenous paraphernalia, this Western clothing signified his chiefly status, but also his relationship with the people who gave him this piece of clothing. It thus seems that both colonial and local agents perceived specific artefacts as tokens of particular people. But for Maisin, these objects also signified the relationship they had with each other.

111 Gosden and Knowles, Collecting Colonialism, pp. 10, 22

112 Hermkens, Engendering Objects, pp. 249-88. 


\section{Materialising the mission}

In addition to collecting and exchange, the missionary project materialised through the erection of mission stations and schools, changes in village layout, the introduction of a crude form of currency and populations being counted. The first thing the Anglican missionaries did, was build, or try to build, a mission station, thereby materialising their project and goals. The fact that the Anglican Mission actually relied on the success of such material projects becomes clear when considering the debacle in Sinapa. As the building of a good mission station initially failed in Sinapa, the mission had also, symbolically, failed. In a similar way, the missionisation of Maisin people could only start as soon they accepted the building of a church and school in Uiaku. So, the materialisations of churches, schools and the changes of village layout, contributed to the ideological successes of the missionary project. This was particularly so for the Anglican Bishop Stone-Wigg, who urged missionary Money to make haste with the "expansion" of the Anglican mission by building missionary houses and schools in villages like Sinapa. These buildings not only materialised the efforts and ideals of the mission, they also made it possible to keep track of the progress the mission was making. By counting church and school attendants the missionaries got a "physical" grip on the local people and their commitment to the church and education.

As Barker argued, both government and mission identified villages "as the primary venues of control," putting much effort in defining localities and the people living in them. ${ }^{113}$ Due to colonial governance and the Anglican mission, not only were "new" buildings, or materialities, embedded in a local setting, local people were forced or encouraged to also change their own settlements. Both residential administrators and missionaries demanded settlement near the coast in order to facilitate colonial patrols and inspections. Under the guidance of missionary Abbot and teacher Nogar, the local village layout in Wanigela was changed from traditional patterns into rows of houses, although not all missionaries agreed with this change. In addition, all Maisin villages were restructured to create greater space between houses and with burial places outside the village in order to improve the hygiene and health of the people. ${ }^{114}$

From the early patrol reports onwards, the population of each Maisin village was counted, thereby making, as Michael Rowlands argues, the local people "visible." 115 Moreover, these counts enabled physical control. For example, in 1960 it was reported that 50 percent of the Airara population was absent,

113 John Barker, “Village interventions: historical variations upon a regional theme in Uiaku, Papua New Guinea," Oceania 66(3) (1996): 211-29, p. 213.

114 Patrol Report, Year 1948-1949, National Archives of Papua New Guinea, Port Moresby; Patrol Report, Year 1967-1968, National Archives of Papua New Guinea, Port Moresby.

115 Rowlands, "A materialist approach to materiality." 
leaving eighty-seven people in the village. ${ }^{116}$ The large number of people absent led the Patrol Officer in charge to have people report when leaving Airara. As he noted, "This will allow a closer check to be kept on absenteeism within that village." ${ }^{\prime 17}$ As with the registering of church and school attendants, this counting materialised indigenous bodies in such a way that they, indeed, became visible.

\section{Materialising bodies}

The notion of "materialising" bodies, of making indigenous people visible to the colonial enterprise, was in many other areas put into practice by dressing people. This preoccupation with clothing, or the lack thereof, focused in particular on local women and reflected European notions about clothing in relation to themes such as civilisation, morality, sexuality and the position of local women. ${ }^{118}$ Viewed within colonial contexts, women's bodies and their sexuality became central to representations of colonial dominance. ${ }^{119}$ Although some missionaries, like Henri Newton, preferred Western dress, in general missionaries stationed in Collingwood Bay seemed not much concerned with "dressing up" local bodies. Only those living on the station and having married into the mission seem to have worn Western clothing, as evidenced by a photograph in the Wanigela log showing Sara Siru wearing a short shell-necklace, earrings and a blouse. ${ }^{120}$ Mission boys are reported to have worn red or white calico during special occasions. ${ }^{121}$ According to Wetherell, "Missionaries who clothed Papuans were the exception rather than the rule; and Anglican missionaries more frequently lamented the desire of Papuans for European clothes than complained about immodest dress." ${ }^{122}$ However, in North Vanuatu, where Anglicanism was strong, Anglicans were determined to re-clothe women's bodies. ${ }^{123}$ Among Maisin people, Anglican missionaries insisted on removing corporeal signs of women's heathen identity. This was done by stripping tapa cloths and decorations from

\footnotetext{
116 Patrol Report, Year 1959-60, National Archives of Papua New Guinea, Port Moresby, p. 3.

117 Patrol Report, Year 1960-61, National Archives of Papua New Guinea, Port Moresby, p. 3.

118 Hermkens, "Gendered objects," p. 12.

119 Ann Laura Stoler, Carnal Knowledge and Imperial Power. Race and the Intimate in Colonial Rule, Berkeley: University of California Press, 2010 [2002].

120 Wanigela log book, April 1907-September 1916, Anglican Archives, Port Moresby, Box 25, File 4. Sara Siru's photograph was placed between the entries of June and July 1913, mentioning only the heading "Sara Siru."

121 Chignell, An Outpost in Papua, p. 89

122 Wetherell, Reluctant Mission, p. 202.

123 On this matter, Tom Harrisson has commented: "The pastors made an absolute distinction between native and European clothing. A native could not be a Christian in his own clothes; no Christian woman could show her breasts, as every woman has done before." See Harrisson, Savage Civilization, London: Victor Gollancz, 1937, p. 153 and see especially quote from Bishop Selwyn of Melanesian Mission at p. 154. Felix Speiser also noted that "as clothing has increased, the areas of shame have also grown, so that Christian women dare show nothing of their bodies but the face, hands and feet." Speiser, Ethnology of Vanuatu: An Early Twentieth-century Study, Spinger-Verlag, 1923, republished in English translation, Bathurst: Crawford House, 1990, p. 183. See also Margaret Jolly, "A saturated history of Christianity and cloth in Oceania," this volume, chapter 16 .
} 
women's bodies, which occurred in specific instances, but more specifically, by trying to control female sexuality, and abolish corporeal customs that are very much part of women's sexual and social identity, such as facial tattooing and mourning practices.

Mission sites were arguably sites of collecting, but also "sites of desire," in which not only objects, but also modes of sexuality were cross-culturally exchanged. ${ }^{124}$ In Collingwood Bay, the mode of the Anglican missionaries, with their emphasis on maintaining their own celibacy while promoting Christian marriage, contrasted strongly with local mores, which encouraged young people to have sexual relationships before traditional marriage. According to Wetherell, it was especially the South Sea islanders who were troubled by the state of celibacy in which Anglican agents were enjoined to live. However, Percy Money, in one of his letters to the Bishop also confesses to be troubled by the temptation of local women and how hard it must be, especially for the South Sea islander teachers, to maintain their celibacy. James Nogar seems to have been so plagued by local women that in November 1900 he appealed to Stone-Wigg, "My Lord remember me in your prayers to God because temptation [is] very strong." ${ }^{125}$ In May 1903, Nogar decided to end his state of celibacy by marrying Mary, while Money ended his celibacy by marrying Annie Ker in 1909.

While the missionaries stationed in Wanigela and Uiaku strongly condemned adultery, often punishing both man and woman, they were also against sexual relations between unmarried men and women, especially when it concerned Christian people "falling into the heathen custom of sleeping together." ${ }^{126}$ Both the Uiaku and Wanigela logs regularly mention unmarried couples running off into the bush, which, even after having settled in the area for almost twenty years, still managed to shock the missionaries in charge. Whenever possible, they would take measures against this behaviour and punish the lovers. In 1917, Maisin received their own priest, missionary Arthur Prout Jennings. Jennings especially seemed to have been strongly opposed to premarital liaisons. As the Uiaku log of 26 August 1917 tells us, "Six girls had to be punished today for fornication. One of the guilty boys was Louis, Mr. Jennings' houseboy. He was caned and will be sent back to his home at Wanigela. The six girls will be suspended from Communion for a time, probably till Christmas."127

However, the girls were not only suspended from Communion. A few days later, they "were ordered to have their heads shaved and to remove all ornaments

\footnotetext{
124 Lenore Manderson and Margaret Jolly (eds), Sites of Desire/Economics of Pleasure: Sexualities in Asia and the Pacific, Chicago: Chicago University Press. 1997.

125 Wetherell, “"The bridegroom cometh,'” p. 63.

126 Henri Newton, Dogura, to the Bishop. May 31, 1902. Anglican Archives, Port Moresby, Box 22, file $3 a$ and $3 \mathrm{~b}$.

127 Uiaku logbook, entry on 2 September 1917. Anglican Archives, Port Moresby.
} 
from their persons." ${ }^{128}$ Obviously, by removing their hair and decorations, their alleged immoral behaviour was made visible to the outside world. While one of the boys involved was caned, this punishment of girls was actually more severe. The pain of being hit (and in the boy's case being sent home) is neither visible nor enduring, while it would take several months for the girls' hair to grow to its normal length. The main reason for this act seems to have been to prevent these girls from attending the mangu-via, the moonlight beach dances, during which boys and girls would meet. The punishment would have been an incredibly shaming act, in which the shame was literally worn on the body for several months. ${ }^{129}$ Likewise, the removal of personal regalia contributed to this public display of shame and, moreover, erasure of the girls' identity. Maisin decorations communicate values of clan and gender identity, as well as notions of sexual attractiveness and health. But they do more than communicate or mediate; decorations define and establish notions of personhood, which are acted and performed within specific socio-cultural settings. As such, they do not just represent identity. Body decorations are not symbols that stand for something else; they are embodiments of cultural values, ancestral connections and specific identities. Removing ornaments from the body actually deconstructs a person's social identity. So, the girls' punishment was not just a temporary alteration of their bodies, but a profound deconstruction of their identity.

The practice of addressing girls' or women's bodies, display and conduct, was not entirely incidental. Various missionaries placed emphasis on girls and women, trying to change their conduct and especially their corporeal behaviour. In 1916, at a meeting held in the Wanigela Church, Chignell's successor J.E.J. Fisher, declared that certain customs had to stop, and stated:

That the behaviour of women at funerals and deaths must be modified; That the puberty ceremony, both in the case of boys and girls, must cease; That there must be a ... case taken of maidens to prevent sinbehaviour; That mothers must take more care of young babies; That women must exercise their influence in the right direction; That women must try to realize more than they do, the part that Christianity has come to play in their lives. ${ }^{130}$

Fisher was directly instructing women to act as role-models for the Anglican Church and to use their influence to change society as a whole. Women's behaviour, and especially their bodily conduct was placed under scrutiny, it had to be changed. The bodily changes Fisher urged, would refashion women's bodies into silent, clean and disciplined bodies. If it were up to Fisher, women

128 Ibid.

129 See also Andrew Strathern, “Why is shame on the skin?" Ethnology 14(4) (1975): 347-56.

130 Wanigela logbook, entry on 15 May 1916, Anglican Archives, Port Moresby. 
could no longer wail and mutilate their bodies during mourning and funerals. They could no longer tattoo their daughters', or female relatives' faces as part of the female puberty-rituals. And women were ordered to take particular care of their daughters and other young girls to prevent immoral conduct. Although Fisher opposed puberty-rituals for boys as well, these rites did not entail the profound bodily transformation that girls' initiation did. As a consequence, boys' bodies were less "refashioned" by this ordinance.

While Fisher worked for physical and moral reform in Wanigela, Jennings, who was appointed as head of Uiaku station, likewise took measures to stop several customs he found offensive. ${ }^{131} \mathrm{He}$ was equally opposed to mourning practices, against the facial tattooing of schoolgirls, and as we saw earlier, ordered girl's heads to be shaven as punishment for sleeping with boys. ${ }^{132}$ It thus seems that both Jennings and Fisher tried to reconstitute, in particular, girls' and women's bodies, "and through this, their moral constitution." ${ }^{133}$ It must be noted that both missionaries faced considerable local resistance and were eventually forced to leave-Jennings after only three years. However, the notion of bodily reform as essential for inward or moral reform was central in Christian rhetoric. ${ }^{134}$ Sara's story at the beginning of this paper already revealed the emphasis placed on physical transformation. Taking care of one's body, and thus being clean, clothed and confident, as well as neat and orderly, was indicative of a disciplined Christian. As Money mentions in relation to health and sickness: "Care of the body is closely akin to the care of the soul." ${ }^{135}$ But, why this emphasis on women? As indicated by other studies concerning missionary practices, local women were often used to implement Christian morals and virtues, after which they could serve as Christian role-models. ${ }^{136}$ Women, in their roles as housewives and mothers, provided a means for targeting society as a whole. "It was thought that when the women and girls had undergone a process of education leading to their moral improvement, this would lead to the moral re-generation of society as a whole, through their example." ${ }^{137}$ In Collingwood Bay, such exemplary rolemodels of Christian housewives were to be found among the local women who had married into to the mission, such as Sara and Mary, whose "native" skills had been modified at Dogura.

\footnotetext{
131 Barker, "Cheerful pragmatists," pp. 76-78.

132 While initially Jennings' relationship with Uiaku villagers seemed to be fairly positive, relations became increasingly sour and stressed, resulting in Jennings' departure in 1920. See Barker, “Cheerful pragmatists," p. 78.

133 Richard Eves, "Colonialism, corporeality and character: Methodist missions and the refashioning of bodies in the Pacific," History and Anthropology 10(1) (1996): 85-138, p. 85.

134 Eves, “Colonialism, corporeality and character," p. 86.

135 Percy John Money, Wanigela, to the Bishop, August 21, 1905, Anglican Archives, Port Moresby, Box 21, file 23 .

136 Eves, "Colonialism, corporeality and character"; Kathryn Rountree, "Re-making the Maori female body: Marianne Williams' Mission in the Bay of Islands, Journal of Pacific History 35(1) (2000): 49-66.

137 Eves, “Colonialism, corporeality and character," p. 103.
} 
However, not all missionaries in charge of Uiaku and Wanigela station were concerned with the reformation of women's bodies to the same degree. Money, for example, never actually forbade women's wailing at a time of death, nor had he opposed facial tattooing. In fact, he made numerous photographs of Uiaku schoolgirls showing their newly obtained facial tattoos and seemed rather intrigued by them. However, like his successors, Money was equally opposed to various other practices associated with mourning, like widow self-mutilation and seclusion. ${ }^{138}$

While many of these intended reforms did not take place, as Maisin people were clearly not willing to give them up, some aspects regarding women's bodily behaviour did change. Customs of self-mutilation were indeed abolished and, as argued by Maisin today, the missionaries urged men to help their wives more, thereby easing some of the burden that was placed on women. Moreover, girls and women regularly sought help from the missionaries in order to get rid of an unwanted lover, to prevent an unwanted marriage and possibly abduction, ${ }^{139}$ or even to help them move to the mission station so as to prevent male advances. "The girls of the hearers' class told Mr. Money that they were being troubled by the advances of young men, and asked him to write and ask for a lady to be sent so that they can come and live on the mission station. They do not wish to stay in their village." 140

It seems that although attempts were made to change girls' and women's conduct in particular, the missionaries also seem to have liberated local women from "oppressive" gender relations. On the part of the colonised women, it seems that "education and conversion became technologies of self-control that enabled subordination at the same time that they structured resistance to colonialism," albeit not so much against Christianity as against local gender relations. This relationship between the Anglican Church and women's position in Maisin societies is still in process. Women are among the most loyal adherents of the church, both through their attendance at Sunday services and their work in the Mother's Union. Moreover, their organisation in the Mother's Union enables them to cross gender, clan and village boundaries that tend to restrict women's movement in Collingwood Bay, and beyond.

\footnotetext{
138 Percy John Money, "Notes and news from the staff," Wanigela, 30 August 1905, Anglican Archives, Box 5, file 8 .

139 Percy John Money, Wanigela, to the Tufi Resident Magistrate, 3 September 1903, Anglican Archives, Port Moresby, Wanigera letterbook 1902-1907, Box 25, file 3, AL C563. 6A3.

140 Uiaku logbook, entry 25 October 1908, Anglican Archives, Port Moresby.

141 Peter Pels, "The anthropology of colonialism: culture, history, and the emergence of Western governmentality," Annual Review of Anthropology 26 (1997): 163-183, p. 172.
} 


\section{Conclusion}

In this paper I have engaged with colonial representations, not so much by focusing on textual strategies, but by elucidating the visual and tangible dimensions of colonial encounters and their social practices. As argued by Peter Pels in his review of the anthropology of colonialism, such a perspective enables us to fully grasp "the contradictions and paradoxes of specific microphysics of colonial struggle, encounters, (knowledge) production and exchange." 142 Here, I have focused on the interplay between colonialism, collecting and the exchange of objects, at the same time illustrating how missionaries materialised new forms of domesticity through the arrangement and disposition of bodies, ornaments and clothes, and the erection of churches, schools and mission stations.

Since the first documented encounters between colonial agents and Collingwood Bay people around the 1890s, objects have been continuously exchanged. The majority of Maisin objects collected at the end of the nineteenth century ended up in museums in England and Australia, but also in other countries, such as the Netherlands and Switzerland, and even in the United States of America. I think it is no coincidence that the main agents involved in the colonial project of pacifying and Christianising Collingwood Bay people and Maisin in particular, were engaged in the collecting of objects.

The exchange of goods was essential in establishing relationships, both between colonial agents and between Europeans and indigenous people. The collecting of tapa by Western colonial agents, but also by South Sea islander teachers such as James Nogar, were part of an ongoing exchange between colonial and local agents and events. In fact, colonialism implied a dialogue and exchange of both goods and ideas between the various men and women involved. Importantly, by collecting material culture, missionaries not only collect physical artefacts. As shown by several scholars, the act of collecting can be regarded as a primary means of producing knowledge. ${ }^{143}$ But by collecting objects from others, we are also "collecting ourselves." ${ }^{144}$ Indeed "collecting and display" have come to be seen "as crucial processes of Western identity formation."145

For MacGregor, effective colonisation entailed a familiarisation with the colonised subjects, and one way of knowing these subjects was through the

\footnotetext{
142 Pels, "The anthropology of colonialism," p. 169.

143 Nicholas Thomas, Entangled Objects: Exchange, Material Culture, and Colonialism in the Pacific, Cambridge, MA: Harvard University Press, 1991; Quinnell, "Before it has become too late"; Fred R. Myers, "Introduction, The Empire of Things," in The Empire of Things. Regimes of Value and Material Culture, ed. Fred R. Myers, Oxford: James Currey, 2001, pp. 1-60.

144 James Clifford, The Predicament of Culture: Twentieth Century Ethnography, Literature and Art, Cambridge: Harvard University Press, 1988; John Elsner and Roger Cardinal, "Introduction," in The Cultures of Collecting, ed. John Elsner and Roger Cardinal, London: Reaktion Books, 1994, pp. 1-6.

145 Clifford, The Predicament of Culture, p. 220.
} 
extensive collecting of objects. Since MacGregor wanted to rule foremost in peace, his pledge to know the people of Papua embodied an extensive exploration of both country and people. By collecting their artefacts, MacGregor tried to understand them, but he also wanted to document their culture before, ironically, it would be affected and changed by white civilisation. Stone-tools, weapons and pots were collected as "tokens of industry," or rather as a vanishing "archaic" technology. ${ }^{146}$ It seems that by collecting stone tools and weapons, MacGregor's effort of pacifying Papuan men was visualised, and as such at least materially accomplished. In a similar way, Money's collection of charms and other attributes related to customs to which he objected seem to both document and thereby visualise the change that had taken place precisely due to his own efforts of Christianisation. By collecting body decorations such as ornaments and decorated tapa, indigenous bodies were in a sense appropriated by the collectors, and re-contextualised.

Anglican Bishop Stone-Wigg, for example, not only set up a missionary museum, urging his missionaries to collect artefacts, he also used these so-called "curios" from areas such as Collingwood Bay to display to his audiences in England the benefits of civilisation and Christianity. King Edward VII was very interested in the artefacts and fancied the British Museum as a suitable place for their display. ${ }^{147}$ However, the British audiences were far more interested in the contents of a black bag brought by the Bishop to his presentations, which contained the bones of a boy killed and eaten during a raid. His jawbone symbolised the savagery of the Papuans and the need for mission work in New Guinea. "Congregations told that there would be more jawbones unless the work of the New Guinea mission was supported." ${ }^{148}$

According to Mary Taylor Huber and Nancy C. Lutkehaus, colonialism was a manly act, while "the missionary enterprise was gendered as 'feminine'."149 The way MacGregor ventured into Collingwood Bay, travelling and being aided by Papuan and white men, and moreover, mainly encountering and trading with local men, does indeed suggest that colonialism, as put into practice by the Government representative, was a manly act. However, what about the Anglican Mission in Collingwood Bay; was this indeed a feminine enterprise? In Collingwood Bay, this seems partially to have been the case. While government efforts were mainly targeted towards pacifying men by either force or Christianisation, missionaries in Collingwood first targeted young boys, who were trained and housed on the mission station. Efforts to bring moral reform,

\footnotetext{
146 Thomas, Entangled Objects, p. 175.

147 Wetherell, Reluctant Mission, p. 38.

148 Ibid.

149 Mary Taylor Huber and Nancy C. Lutkehaus, "Introduction: gendered missions at home and abroad," in Gendered Missions. Women and Men in Missionary Discourse, ed. Huber and Lutkehaus, Ann Arbor: University of Michigan Press, 1999, 1-38, p. 12.
} 
however, seem to have been especially addressed to women. As we have seen, missionaries' "ideals of domesticity," ${ }^{150}$ entailed in Collingwood Bay in particular ideals about morality and women's bodily constitution. For some missionaries, this ideal entailed the abolition of facial tattoos, self-mutilation and wailing, while for others, this ideal meant that mainly "oppressive" customs, such as self-mutilation, had to be stopped, especially in relation to women's bodies.

What this chapter foregrounds is the paradox of colonial collecting. While for some collectors, their collection of Collingwood Bay artefacts and photographs were part of an effort to document a vanishing culture, at the same time, their collecting activities introduced new forms of materiality that were part of the colonial project to exercise control over native subjects and "domesticate" them. Collecting can actually be seen as a project of domestication through which Collingwood Bay and its people were pacified through the removal of weapons and the creation of new Christian selves focused on families. Women were domesticated by removing their "dirty" dress and regalia, and moreover, by trying to abolish other corporeal signs of women's native, heathen identity, such as facial tattoos and self-mutilation.

Although the collectors considered here and their collections are embedded within a political colonial discourse, a close look at their personal (and often unpublished) writings and photographs reveals a more subjective, localised, point of view. Thus a distinction can and must be made between private and public propagandistic accounts. The prior anecdotes reveal how colonialism was not just a political discourse, but rather, a cultural process with a particular localised character. The biographies of the missionaries discussed in this paper are specific accounts that give insight into the vanished articulations of colonising and counter-colonial representations and practices.

As Sara Manua's genealogy shows, colonialism was not just an abstract power that interfered with people's lives. Colonialism was made up of embodied gendered agents, acting and responding to various people, events and contexts. Moreover, as shown earlier, colonial interactions were not one-directional but mutual. ${ }^{151}$ According to Newton, Sara begged him to let her stay some extra months at Dogura as she was eager to learn more. ${ }^{152}$ Other girls requested the missionary in charge to protect them from advances posed by local or other men, or asked them to arrange their marriages. These examples show how missionaries to a certain extent liberated local women in the process of Christianising them,

150 Margaret Jolly and Martha Macintyre (eds), Family and Gender in the Pacific: Domestic Contradictions and the Colonial Impact, Cambridge: Cambridge University Press, 1989; Huber and Lutkehaus, "Introduction: gendered missions at home and abroad," p. 12.

151 See also Bronwen Douglas, "Slippery word, ambiguous praxis: 'race' and late 18th-century voyagers in Oceania," Journal of Pacific History 41(1) (2006): 1-29.

152 Newton, In Far New Guinea, p. 269. 
but they also exemplify how local women (and men) were willing to incorporate new ideas, and even use the missionaries to protect their interests and have their desires fulfilled.

\section{Acknowledgements}

I thank the various ethnographic museums and their staff for supporting my study of their Collingwood Bay collections and archives. My ethnographic fieldwork among the Maisin $(2001-2002 ; 2004)$ has been made possible thanks to a research grant from the Netherlands Organization for the Advancement of Tropical Research (WOTRO) and the Institute for Gender Studies, Radboud University Nijmegen, Netherlands. A special thanks to John Barker, who greatly supported and aided me with my research, and gave helpful comments on this paper as well as the volume's editors, Hyaeweol Choi and Margaret Jolly.

The chapter was written while I was a post-doctoral fellow in the ARC Laureate Project held by Professor Margaret Jolly, Engendering Persons, Transforming Things: Christianities, Commodities and Individualism in Oceania. 
This text taken from Divine Domesticities: Christian paradoxes in Asia and the Pacific, edited by Hyaeweol Choi and Margaret Jolly, published 2014 by ANU Press, The Australian National University, Canberra, Australia. 